DOI: 10.33766/2524-0323.89.63-71

УДК 343.136:343.18

М. С. Городецька,

кандидат юридичних наук, слідчий слідчого відділу

Криворізького відділу полічії ГУНП в Дніпропетровській області (м. Кривий Ріг, Україна) e-mail: loskutovagorodetskaya@gmail.com iDhttps://orcid.org/0000-0002-3228-6299

\title{
ЗАБЕЗПЕЧЕННЯ ЕФЕКТИВНОСТІ КРИМІНАЛЬНОГО ПРОВАДЖЕННЯ ЯК ОДИН ІЗ АСПЕКТІВ ФУНКЩОНАЛЬНОГО ПРИЗНАЧЕННЯ ПРЕДМЕТУ ВІДАННЯ
}

У статті розглядається один із аспектів функціонального призначення предмету відання, який полягає в забезпеченні ефективності кримінального провадження. На підставі аналізу різних теоретичних позицій учених робиться висновок, що спільним у функціональному призначенні предмету відання суб'єктів кримінального процесу є забезпечення ефективності провадження, забезпечення прав учасників, забезпечення законності. Підсумовується, що забезпечення ефективності кримінального провадження у зв'язку з розподілом предмету відання відбувається шляхом такого розподілу: 1) праці між суб̆єктами одного рівня; 2) праці між суб'єктами-виконавцями та владними суб'єктами; 3) контролю та оцінки результатів діяльності суб'єктів кримінального провадження за визначеними предметами відання.

Ключові слова: предмет відання, компетенція, суб'єкт кримінального провадження, функціональне призначення, ефективність кримінального процесу, спеціалізація.

Постановка проблеми. Кожний суб'єкт, який веде кримінальне провадження, наділений предметом відання, який становить сферу публічних справ, щодо яких суб̆єкт уповноважений застосувати свої повноваження задля здійснення кримінальної процесуальної функції. Розподіл предмету відання між суб'єктами, визначення його обсягу та змісту мають відбуватися з урахуванням функціонального призначення даного поняття, щоб забезпечити оптимальний шлях виконання останнього в системі кримінального процесу. Оскільки невідповідність певних ознак предмету відання його функціональному призначенню призведе до того, що даний системний компонент буде порушувати загальний баланс та стане деструктивним елементом. Отже, для оптимального розподілу предмету відання між суб'єктами кримінального судочинства необхідно дослідити його функціональнепризначення, 3 яким такий розподіл має узгоджуватися.

Аналіз останніх досліджень і публікацій. Деякі аспекти функціонального призначення предмету відання в кримінальному провадженні досліджували такі вчені, як: Ю. М. Грошевий, В. С Зеленецький, О. В. Капліна, Л. М. Лобойко, С. В. Оверчук, А. А. Омаров, М. А. Погорецький, О. Ю. Татаров, В. І. Шишкін та інші. Утім, у перебігу досліджень вчені зосереджувалися на функціональному призначенні компетенції суб'єктів, підслідності, підсудності тощо. Проте не були охоплені всі питання, зокрема вченими не акцентувалася увага на розгляді забезпечення

() Городецька М. С., 2020 
ефективності кримінального провадження як одного із аспектів функціонального призначення предмету відання суб'єктів кримінального процесу.

Формулювання цілей. Метою даної статті є дослідження забезпечення ефективності кримінального провадження як одного із аспектів функціонального призначення предмету відання. Для досягнення цієї мети необхідно таке: проаналізувати теоретичні точки зору щодо функціонального призначення предмету відання; визначити шляхи забезпечення ефективності кримінального провадження, пов' язані з розподілом предмету відання суб'єктів кримінального процесу.

Виклад основного матеріалу. Дослідження будь-якого поняття не обходиться без визначення його функщії в загальному процесі. Так і щодо предмету відання. У контексті його дослідження в кримінальному процесі необхідно визначити його функціональне призначення, тобто відповісти на питання про те, навіщо потрібен даний елемент, на що він впливає та до яких результатів призводить його реалізація.

Для з'ясування функціонального призначення предмету відання в кримінальному процесі проаналізуємо теоретичні розробки вчених щодо суміжних понять.

Досліджуючи кримінально-процесуальну компетенщію, Л. М. Лобойко визначив такі ії функції: 1) забезпечення реалізації публічних інтересів у сфері кримінального судочинства й надання офіційності діяльності органів дізнання, досудового слідства, прокуратури й суду; 2) забезпечення правозастосування у зв'язку із виникненням у суспільстві кримінально-правових конфліктів; 3) розподіл сфер впливу державних органів і посадових осіб під час провадження в кримінальних справах; 4) визначення міри дозволенної поведінки органів дізнання, досудового слідства, прокуратури й суду; 5) розмежування кримінально-процесуальних функцій $[1$, с. 53-61].

Щодо функщіонального призначення підслідності, на думку О. В. Селютіна, правильне визначення підслідності забезпечує таке: 1) виконання встановлених законом правил щодо розслідування кримінальних справ компетентними органами; 2) забезпечує права учасників процесу; 3) підвищення виховної ролі кримінального процесу (правильне вирішення питання щодо підслідності забезпечує більшу увагу населення до розслідування кримінальних справ і тим самим підвищує виховний вплив кримінального процесу); 4) своєчасне та кваліфіковане розслідування, чим забезпечує найбілыш успішну боротьбу зі злочинністю (оскільки деякі види злочинів держава віднесла до розслідування певним слідчим органам 3 відповідною кваліфікацією, досвідом та кадрами) [1, с. 171-174].

О. С. Козерацька зазначає, що підслідність кримінальних правопорушень $є$ одним 3 процесуальних інститутів, пов'язаних із забезпеченням гарантій прав i законних інтересів особи в кримінальному судочинстві [3, с. 106].

С. В. Оверчук, аналізуючи терміни, споріднені з підсудністю, робить висновок, що інститут підвідомчості слугує розмежуванню кола питань між судами та іншими юрисдикційними органами, а інститут підсудності - розмежуванню віднесених судовою підвідомчістю юридичних справ між судами усередині єдиної судової системи щодо їх розгляду по першій інстанщії [4, с. 25].

Щодо інституту підслідності, їі вагомості для злагодженого функціонування механізму кримінального судочинства, А. А. Омаров зазначає, що переоцінити ії 
доволі складно, з урахуванням багатоаспектності та різновекторності впливу вказаного інституту на процедуру кримінального провадження. Автор вважає, що значення підслідності полягає в такому: 1) виступає інструментом кримінальної процесуальної політики держави; 2) дозволяє оптимізувати діяльність із здійснення досудового провадження; 3) дозволяє уникнути ситуацій, за яких одне й те саме кримінальне правопорушення одночасно окремо розслідується різними органами досудового розслідування або різними слідчими в межах одного органу досудового розслідування; 4) значення підслідності полягає в забезпеченні дії механізму передачі кримінальних проваджень від одного органу досудового розслідування до іншого у випадку виникнення спорів про підслідність; 5) норми відповідного інституту виступають як своєрідні гарантії реалізації прав та законних інтересів осіб, щодо яких здійснюється кримінальне переслідування та інших учасників процесуальної діяльності; 6) правильне визначення підсудності є гарантією отримання доказів, що відповідають вимогам допустимості; 7) сприяє недопущенню виникнення кримінальних процесуальних спорів, міжвідомчих конфліктів щодо розмежування компетенщії тощо, а в разі їх виникнення - оперативному та злагодженому вирішенню такого роду спорів [5, с. 28-30].

Аналізуючи різні позиції вчених, можна зазначити, що спільним у функціональному призначенні предмету відання суб'єктів кримінального процесу є забезпечення ефективності провадження, забезпечення прав учасників, забезпечення законності тощо.

Зупинимося на більш докладному дослідженні такого аспекту функщіонального призначення предмету відання суб'єктів кримінального процесу як забезпечення ефективності провадження.

Однією з умов підвищення ефективності кримінального процесу, пов'язаною з розподілом предмету відання, є підвищення компетентності суб'єктів кримінального провадження.

Визначення окремих предметів відання для окремих суб'єктів є нічим іншим, як певним розподілом праці між суб'єктами. За Е. О. Дюркгеймом, розподіл праці підвищує виробництво та обізнаність працівника. Роль такого розподілу праці полягає саме в тому, що він одночасно підвищує виробничу силу (потужність) та вміння працівника [6, с. 52].

Спеціалізація сприяє удосконаленню майстерності суб'єктів кримінального процесу щодо проваджень певної категорії. Удосконалення такої майстерності пов'язане 3 поглибленням знань суб'єкта щодо провадження певної категорії кримінальних правопорушень. Але вузька спеціалізація суб'єкта призводить до того, що стосовно інших категорій він втрачає кваліфікащію. Дійсно, спеціалізація має в деякому розумінні подвійний характер, оскільки до певної міри підвищує продуктивність праці, проте за умови надмірного застосування може призводити до протилежного негативного ефекту.

Щодо спеціалізації права, О. М. Овчаренко зазначає, що вона становить собою таку сукупність взаємозумовлюючих чинників, які знаходять свій вияв як у звуженні людської діяльності, обмеженні функціональних параметрів, так і в конщентрації, мобілізаціїї зусиль у чітко накресленому напрямку, що в сукупності дозволяс швидко, якісно і з найменшими витратами розв'язувати поставлені завдання. Джерелами юридичної спеціалізації, за визначенням авторки, є суспільний розподіл пращі, 
реально легітимована диференщіація владних структур, національна державна суверенізація. Мета такої спеціалізації, за визначенням О. М. Овчаренко, полягає в тому, щоб якомога повніше й точніше охопити різноманітні особливості, новизну й динаміку соціальних перетворень, відбиття якісного стану таких реформ [7, с. 93].

Аналізуючи спеціалізацію праці, Ю. А. Сременко робить такі висновки: 1) спеціалізація праці має значний вплив на їі продуктивність; 2) вплив спеціалізації на продуктивність праці проявляється в зростанні продуктивності праці або ж їі спаді; 3) існує рівень спеціалізащії, який надає найбільшу користь продуктивності праці, найефективніший; 4) введення спеціалізації від початкового етапу до рівня найбільш корисного здійснює значний позитивний вплив на продуктивність праці; 5) надмірна спеціалізація несе відвертий негативний вплив на продуктивність праці [8, с. 37].

На думку А. А. Омарова, принцип спеціалізації, який покладено в основу окремих видів підслідності (предметної, персональної) дозволяє визначити орган, який буде проводити досудове розслідування, який найбілыш ефективно зможе здійснювати розслідування кримінальних правопорушень певного виду. Це, своєю чергою, має прямий вплив і на проведення кадрової політики держави у сфері протидії злочинності. Так, наприклад, при формуванні кадрового штату відділів по боротьбі з економічними злочинами, за загальним правилом, перевагу віддають слідчим, що мають, окрім юридичної освіти, ще й економічну. Також норми інституту підслідності покликані сприяти заощадженню й економії ресурсів. Спеціалізація слідчих, що здійснюється навіть у межах одного органу досудового розслідування, 3 огляду на їх вузькопрофільний досвід, дозволяє скоротити строк проведення досудового розслідування, уникнути проведення зайвих перевірочних процесуальних заходів тощо [5, с. 28-29].

Розподіл праці застосовується, окрім як задля забезпечення більш кваліфікованого опрацювання за рахунок спещіалізащії однорівневих суб'єктів, також для організації праці. Організація праці здійснюється за рахунок виокремлення керуючих суб'єктів, що також підвищує ефективність діяльності.

Особливим видом діяльності, «який перетворює неорганізований натовп у ефективну й продуктивну групу», є управління або менеджмент. Соціальне управління наявне в будь-якому варіанті спільної діяльноті людей: у державному, громадському, приватному, сімейному [9, с. 45-46].

Необхідність здійснення щодо суб'єктів провадження керуючого впливу, що, звичайно, здійснює вплив на предмет відання у вигляді реалізації прав учасників кримінального провадження, створює підстави для залучення керуючих суб'єктів. На досудовому розслідуванні керівний вплив на слідчого та на оперативного працівника здійснює прокурор, як процесуальний керівник.

Як справедливо зауважив Р. Г. Ботвінов, прокурор, як процесуальний керівник, здійснює керівництво в конкретному кримінальному провадженні, тоді як сферу забезпечення ефективності слідчого підрозділу, як колективу, опрацьовує керівник органу досудового розслідування. Автор зазначає: «Прокурора цікавить якість розслідування саме в конкретному кримінальному провадженні, навіть якщо це єдиний показник слідчого за місяць. Залишається невикористаним ресурс підвищення 
ефективності кримінального провадження у вигляді управлінського впливу не лише в межах розслідування певного кримінального правопорушення, а в межах соціальної групи, тобто управління слідчим підрозділом. У системі з'являється ніша, яку зайняв такий суб'єкт, як керівник органу досудового розслідування» [10, с. 26].

В основі розподілу праці лежать дві складові: збільшення населення (щільність) та збільшення його нерівномірності, різноякісності [6, с. 238, с. 239].

Дійсно, суспільство є нерівномірним у своєму освітньому рівні, у своїх професійних здібностях. Відповідно, й особи юридичних професій не є рівномірно обізнаними. Розподіл діяльності сторони обвинувачення на діяльність двох, трьох суб'єктів може пояснюватись принципом розподілу праці. Так, на нашу думку, місце суб'єкта вищого компетенційного рівня має посідати більш освічений та більш кваліфікований юрист. Серед суб'єктів сторони обвинувачення можна зазначити, що прокурор обіймає керівну позицію відносно слідчого, відповідно, здійснює більш кваліфіковану та більш відповідальну роботу відносно останнього. Прокурор є суб'єктом вищого компетенційного рівня відносно слідчого, а тому логічним буде пред'явити до кандидатів на здійснення даної функції вищі кваліфікаційні вимоги. Менш кваліфікована праця в межах сторони обвинувачення - робота слідчого під керівництвом прокурора чи робота оперуповноваженого під керівництвом слідчого чи прокурора - не потребує такого ж рівня підготовки та рівня обізнаності, як труд процесуального керівника.

Учені зауважують домінування засади ієрархічності в діяльності органів досудового розслідування, що зумовлює відносини «влади-підкорення». Проте такі відносини зовсім не властиві діяльності суду. Щодо відптравлення правосуддя презюмується брак потреби в будь-якому процесуальному начальникові, який би керував діяльністю. Судє незалежним і підкорюється лише Закону (ст. 6 Закону України «Про судоустрій і статус суддів») [11, с. 26-27].

Виокремлення предмету відання керуючих суб'єктів становить один із аспектів підвищення ефективності кримінальної процесуальної діяльності, що позначається на функціональному призначенні такого поняття, як предмет відання.

Одним із способів забезпечення ефективності діяльності суб'єктів кримінального провадження є їх відповідальність перед суспільством, перед громадськістю, що вимагає застосування громадського контролю.

На думку В. П. Гмирка, передусім має бути створена розвинена система контролю за діяльністю поліції з боку громадянського суспільства [11, с. 31].

Враховуючи дійсно неабияке значення в забезпеченні ефективності діяльності правоохоронних органів системи оцінки та контролю, Н. Куба та Р. Тополевський зазначають, що реформування органів внутрішніх справ України неможливе без перегляду системи оцінки їх роботи. На думку авторів, підвищення довіри населення до поліщії є однією із ключових цілей проведення реформи. I від того, як працюватиме нова патрульна поліція, зазначають вони, залежатиме і те, яким чином громадяни ставитимуться до органів внутрішніх справ в цілому, адже задоволеність діяльністю працівників поліції впливає на готовність громадян допомагати правоохоронщям у випадку необхідності.

У своєму дослідженні Н. Куба та Р. Тополевський пропонують систему оцінки ефективності роботи Національної поліції організувати в рамках 4 блоків: блок зовнішнього оцінювання, блок експертного оцінювання, блок оцінювання реалізації 
громадських пріоритетів охорони правопорядку, блок самооцінки. До блоку зовнішнього оцінювання віднесено соціологічне дослідження. Ключовими показниками проведення такого оцінювання автори визначають рівень довіри громадян: а) до працівників Національної поліції в цілому; б) у територіальному розрізі; в) у спеціалізаційному розрізі [12].

Цікавою є будова оцінки рівня довіри громадян у територіальному розрізі та в спеціалізаційному розрізі. Тобто, ми можемо визначити будову такої оцінки за розподілом територіального та внутрівідомчого предмету відання. Дійсно, оцінка органів розслідування та й інших суб'єктів кримінального провадження найбільш змістовною є за територіальним, відомчим та внутрівідомчим розподілом предмету відання, оскільки дозволить виявити можливу неефективність діяльності суб'єктів територіального підрозділу, або певного відомства, або суб'єктів спеціалізованих щодо певної категорії кримінальних правопорушень.

Висновки. Виходячи з вищезазначеного, маємо такі висновки:

1. Серед теоретичних поглядів учених щодо функціонального призначення предмету відання в кримінальному процесі спільними є такі аспекти: забезпечення ефективності провадження, забезпечення прав учасників, забезпечення законності тощо.

2. Забезпечення ефективності кримінального провадження у зв'язку з розподілом предмету відання відбувається таким шляхом: 1) розподілу пращі між суб'єктами одного рівня, що сприяє підвищенню їх кваліфікації та білыш організованому виробничому процесу; 2) розподілу праці між суб'єктами-виконавцями та владними суб'єктами, що сприяє організащії кримінальної процесуальної діяльності; 3) розподілу контролю та оцінки результатів діяльності суб'єктів кримінального провадження за визначеними предметами відання.

Подальші розвідки можуть здійснюватись щодо дослідження таких аспектів функціонального призначення предмету відання в кримінальному процесі, як: 1) забезпечення доступу до правосуддя у кримінальному процесі; 2) забезпечення правоздатності та дієздатності суб'єктів кримінального провадження.

\section{Використані джерела:}

1. Лобойко Л. М. Кримінально-процесуальна компетенція: монографія. Дніпропетровськ: Дніпропетровський державний університет внутрішніх справ, 2006. 188 с.

2. Селютин А. В. Подследственность, как форма внешнего выражения разграничения компетенции государственных органов и должностных лищ при осуществлении уголовно-процессуальной деятельности. Пробелы в российском законодательстве. 2010. № 1 . C. 171-174.

3. Козерацька О. С. Підслідність кримінальних проваджень злочинів проти безпеки виробництва на досудовому розслідуванні. Матеріали 69-ї наукової конференції професорсько-викладацького складу економіко-правового факультету Одеського наи. університету ім. I. I. Мечникова (м. Одеса, 26-28 листопада 2014 року). Одеса: Астропринт, 2014. С. 106-109.

4. Оверчук С. В. Поняття та види підсудності у кримінальному процесі України: дис. канд. юрид. наук: 12.00 .09 / Київ, 2005. 244 с.

5. Омаров А. А. Інститут підслідності в кримінальному провадженні: дис. канд. юрид. наук: 12.00 .09 / Харків, 2017. 214 с.

6. Дюркгейм Э. О разделении общественного труда. Метод социологии. Москва: Наука, 1990.575 с. 
7. Овчаренко О. М. Доступність правосуддя та гарантії його реалізації: монографія. Х.: Право, 2008.304 c.

8. Єременко Ю. А. Правові та організаційні основи спеціалізації органів прокуратури в Україні: дис. канд. юрид. наук: 12.00 .10 / Київ, 2019. 279 с.

9. Кузьменко О. О. Науковий менеджмент як складова процесу державного управління. Влада. Людина. Закон. 2007. № 6. С. 45-48.

10. Ботвінов Р. Г. Кримінальна процесуальна компетенщія керівника органу досудового розслідування (за матеріалами діяльності слідчих підрозділів органів, що здійснюють контроль за додержанням податкового законодавства) : дис. канд. юрид. наук: 12.00 .09 / Донецьк, 2013. 208 с.

11. Гмирко В. П. Діяльнісний погляд на реструктурізацію кримінального процесу: The attempt of dogmatic shawshank redemption? Правова позиція. 2018. №1(20). С. 21-36.

12. Куба Н., Тополевський Р. Система оцінки ефективності роботи Національної поліщії. Інформація з сайта: Права Людини в Україні. Інформаційний портал Харківської правозахисної групи 15.02.2016. URL: http:/ / khpg.org/index.php?id=1455530110.

\section{References:}

1. Loboiko, L. M. (2006) Kryminalno-protsesualna kompetentsiia. Dnipropetrovsk: Dnipropetrovskyi derzhavnyi universytet vnutrishnikh sprav. [in Ukrainian].

2. Selyutin, A. V. (2010) Podsledstvennost', kak forma vneshnego vyrazheniya razgranicheniya kompetentsii gosudarstvennykh organov i dolzhnostnykh lits pri osushchestvlenii ugolovno-protsessual'noy deyatel'nosti. Probely v rossiyskom zakonodatel'stve- Gaps in Russian law, 1, 171-174. [in Russian].

3. Kozeratska, O. S. (2014) Pidslidnist kryminalnykh provadzhen zlochyniv proty bezpeky vyrobnytstva na dosudovomu rozsliduvanni. Materialy 69-i naukovoi konferentsii profesorskovykladatskoho skladu ekonomiko-pravovoho fakultetu Odeskoho nats. universytetu im. I. I. Mechnykova (m. Odesa, 26-28 lystopada 2014 roku) - Materials of the 69th Scientific Conference of the Faculty of Economics and Law of the Odessa National University. University. II Mechnikov (Odessa, November 26-28, 2014). Odesa: Astroprynt, 106-109. [in Ukrainian].

4. Overchuk, S. V. (2005) Poniattia ta vydy pidsudnosti u kryminalnomu protsesi Ukrainy. Candidate's thesis. Kyiv. [in Ukrainian].

5. Omarov, A. A. (2017) Instytut pidslidnosti v kryminalnomu provadzhenni. Candidate's thesis. Kharkiv. [in Ukrainian].

6. Dyurkgeym, E. (1990) O razdelenii obshchestvennogo truda. Metod sotsiologii. Moskva: Nauka. [in Russian].

7. Ovcharenko, O. M. (2008) Dostupnist pravosuddia ta harantii yoho realizatsii. Kharkiv: Pravo. [in Ukrainian].

8. Yeremenko, Yu. A. (2019) Pravovi ta orhanizatsiini osnovy spetsializatsii orhaniv prokuratury v Ukraini. Candidate's thesis. Kyiv. [in Ukrainian].

9. Kuz'menko, O. O. (2007) Naukoviy menedzhment yak skladova protsesu derzhavnogo upravlinnya. Vlada. Lyudina. Zakon-Power. Man. Law, 6, 45-48. [in Russian].

10. Botvinov, R. H. (2013) Kryminalna protsesualna kompetentsiia kerivnyka orhanu dosudovoho rozsliduvannia (za materialamy diialnosti slidchykh pidrozdiliv orhaniv, shcho zdiisniuiut kontrol za doderzhanniam podatkovoho zakonodavstva). Candidate's thesis. Donetsk. [in Ukrainian].

11. Hmyrko, V. P. (2018) Diialnisnyi pohliad na restrukturizatsiiu kryminalnoho protsesu: The attempt of dogmatic shawshank redemption? Pravova pozytsiia- Legal position, 1, 21-36. [in Ukrainian]. 
12. Kuba, N., Topolevskyi, R. (2016) Cystema otsinky efektyvnosti roboty Natsionalnoi politsii. Informatsiia z saita: Prava Liudyny v Ukraini. Informatsiinyi portal Kharkivskoi pravozakhysnoi hrupy. URL: http://khpg.org/index.php?id=1455530110. [in Ukrainian].

Стаття надіӥииа до редколегії 11.02.2020

Городецкая М. С., кандидат юридических наук, следователь следственного отдела Криворожского отдела полиции ГУНП в Днепропетровской области (г. Кривой Рог, Украина)

\section{ОБЕСПЕЧЕНИЕ ЭФФЕКТИВНОСТИ УГОЛОВНОГО ПРОИЗВОДСТВА КАК ОДИН ИЗ АСПЕКТОВ ФУНКЦИОНАЛЬНОГО НАЗНАЧЕНИЯ ПРЕДМЕТА ВЕДЕНИЯ}

В статье рассматривается один из аспектов функционального назначения предмета ведения, который заключается в обеспечении эффективности уголовного производства. На основании анализа разных теоретических позиций ученых делается вывод, что общим в функциональном назначении предмета ведения субъектов уголовного процесса является обеспечение эффективности производства, обеспечение прав участников, обеспечение законности. Подытоживается, что обеспечение эффективности уголовного производства в связи с распределением предмета ведения происходит путем такого распределения: 1) труда между субъектами одного уровня; 2) труда между субъектамиисполнителями и властными субъектами; 3) контроля и оценки результатов деятельности субъектов уголовного производства по определенным предметам ведения.

Ключевые слова: предмет ведения, компетенция, субъект уголовного производства, функциональное назначение, эффективность уголовного процесса, специализация.

Horodetska M., Ph.D in Law, Investigator of the Investigative Department of the Krivoy Rog Police Department of the Main Directorate of National Police in Dnipropetrovsk Regions (Krivoy Rog, Ukraine)

\section{ENSURING THE EFFECTIVENESS OF CRIMINAL PROCEEDINGS AS AN ASPECT OF THE FUNCTIONAL PURPOSE OF THE SUBJECT MATTER}

The article deals with one of the aspects of the functional purpose of the object of knowledge, which is to ensure the effectiveness of criminal proceedings. Attention is drawn to the fact that the investigations are subject to ways of ensuring the effectiveness of criminal proceedings related to the distribution of the subject matter of the subjects of criminal proceedings. Taking into account the stated purpose of the article, a study was carried out to ensure the effectiveness of criminal proceedings as one of the aspects of the functional purpose of 
the subject of knowledge due to the analysis of theoretical points of view regarding the functional purpose of the object of knowledge; identifying ways of ensuring the effectiveness of criminal proceedings related to the distribution of the subject matter of the subjects of criminal proceedings. Based on the analysis of different theoretical positions of scientists, it is concluded that the common in the functional purpose of the subject of control of the subjects of criminal proceedings is to ensure the efficiency of the proceedings, to ensure the rights of participants, to ensure legality, and so on. It is suggested that a higher level of competence should be held by a more knowledgeable and qualified lawyer. Among the subjects of the prosecution, it can be noted that the prosecutor takes a leading position with respect to the investigator, respectively, performs more qualified and more responsible work relative to the latter. The prosecutor is subject to a higher level of competence with respect to the investigator, and it would therefore be logical to present higher qualification requirements to candidates for the exercise of this function. It is concluded that ensuring the effectiveness of criminal proceedings in connection with the distribution of the subject matter is through: 1) the division of labor between subjects of the same level, which promotes their skills and more organized production process; 2) division of labor between the executing entities and the authorities, which facilitates the organization of criminal proceedings; 3) the distribution of control and evaluation of the results of criminal proceedings by certain subjects of jurisdiction.

Keywords: subject matter, competence, subject of criminal proceedings, functional purpose, effectiveness of criminal proceedings, specialization.

DOI: $10.33766 / 2524-0323.89 .71-79$

УДК 343.222:343.77:349.6(477)

\section{I. Єрофеєв,}

кандидат юридичних наук, науковий співробітник науково-дослідної лабораторії з проблем попередження, припинення та розслідування злочинів територіальними органами Національної поліції України Луганського державного університету внутрішніх справ імені Е. О. Дідоренка (м. Сєвєродонецьк, Україна) e-mail: erofeevnikolay50@gmail.com iDhttps:/ / orcid.org/0000-0001-7679-7341

\section{КРИМІНАЛЬНА ВІДПОВІДАЛЬНІСТЬ ЗА ПРАВОПОРУШЕННЯ У СФЕРІ ОЩНКИ ВПЛИВУ НА ДОВКІЛЛЯ: ПИТАННЯ УДОСКОНАЛЕННЯ ЗАКОНОДАВЧОГО РЕГУЛЮВАННЯ}

У статті проаналізовано стан законодавчого регулювання кримінальної відповідальності за злочини у сфері оцінки впливу на довкілля. Доведено доцільність виділення в КК України окремої статті щодо злочинів, що посягають на встановлений порядок оцінки впливу на довкілля, та визначено склад правопорушень, які мають бути внесені до цієї статті.

Ключові слова: кримінальна відповідальність, злочин у сфері оцінки впливу на довкілля, порушення порядку здійснення оцінки впливу на довкілля, екологічна безпека.

(C) Ерофеєв М. I., 2020 